\title{
International Application Of The Fifth Amendment: Where In The World Is Ernesto Miranda?
}

Patrick J. Reville, B.B.A., J.D., Iona College, USA

\begin{abstract}
In 1966, The United States Supreme Court issued its now legendary decision in Miranda v. Arizona (1), and the practice of criminal law in the United States as was then known, was changed forever. The "Miranda Warnings" became not only the "law of the land" in protecting the rights of the accused, but also resulted in evolution and education in the field of law enforcement, processes that continue to this date. Now comes a series of cases involving international terrorism, and Miranda and its old stable-mate Mapp (2) get trotted out again for a new look, to see whether members of "an international conspiracy--led by Osama Bin Laden and organized through the al Qaeda terrorist network--to kill American citizens and destroy American facilities across the globe"(3), can make a run for the roses using the triple crown of American criminal jurisprudence, The Fourth, Fifth and Sixth Amendments to the Constitution. Two races have been run, and the al Qaeda horsemen have finished out of the money. They now gear up and don their colors for one last run in their quest for exoneration: a date with the U.S. Supreme Court.
\end{abstract}

Keywords: Fifth Amendment, International Terrorism, Miranda, Mapp

\section{INTRODUCTION}

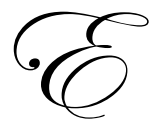

rnesto Miranda was a young man with prior criminal activity and a Dishonorable Discharge from the U.S. Army on his resume. He was someone, clearly, that a young woman would not want to bring home to "meet the parents." In March of 1963, a young woman was kidnapped and sexually assaulted in Phoenix, Arizona, and Ernesto became a suspect. He was interrogated by the police for a few hours, and relatively quickly confessed to the crimes. His later attempts to suppress his confession and evidence seized related thereto/resulting therefrom were denied, and he was convicted in Arizona State Court and sentenced to twenty to thirty years in state prison. His appeal to the highest court in Arizona was denied, and he appealed to the U.S. Supreme Court. The rest, as they say, is history. In a 5-4 split decision (see Figure 2, below), the Court concluded that Miranda's constitutional rights were violated (Fifth, Sixth and Fourteenth Amendments), in that he should have been warned that he had the right to remain silent, the right to an attorney, the right to a free attorney if he had no money to hire one, and that if he did say anything to his interrogators, his statement(s) could and would be used against him in court.(4) These protections/warnings became required procedure for future prosecutions throughout the U.S.A. In August of 1998, perpetrators bombed the American Embassies in Nairobi, Kenya and Dar es Salaam, Tanzania. Statements were made overseas to U.S. and non-U.S. officials by persons suspected of involvement, which said statements were introduced as evidence to obtain convictions of those making the statements and others. The U.S. District Court (Leonard B. Sand, Judge) declined to suppress the statements.(5) The Second Circuit Court Of Appeals agreed with Judge Sand.(6) At this point, the convicted terrorists have one option left: the Supreme Court. 


\section{The Fourth Amendment}

The Fourth Amendment to the U.S. Constitution prohibits unreasonable searches and seizures, and outlines requirements for warrants to issue. The right of the people to be secure in their persons, houses, papers and effects, against unreasonable searches and seizures, shall not be violated, and no Warrants shall issue, but upon probable cause, supported by Oath or affirmation, and particularly describing the place to be searched, and the persons or things to be seized. (7)

\section{The Fifth Amendment}

The Fifth Amendment to the U.S. Constitution has five clauses/protections to it. No person shall be held to answer for a capital, or otherwise infamous crime, unless on a presentation or indictment of a Grand Jury, except in cases arising in the land or naval forces, or in the Militia, when in actual service in time of War or public danger; nor shall any person be subject for the same offense to be twice put in jeopardy of life or limb; nor shall be compelled in any criminal case to be a witness against himself, nor be deprived of life, liberty or property, without due process of law; nor shall private property be taken for public use, without just compensation. (8) The so called, "self incrimination"/ "nor shall be compelled...to be a witness against himself..." portion is operative in the discussion at hand.

\section{The Sixth Amendment}

The Sixth Amendment to the U.S. Constitution has various protections. In all criminal prosecutions, the accused shall enjoy the right to a speedy and public trial, by an impartial jury of the State and district where the crime shall have been committed; which district shall have been previously ascertained by law, and to be informed of the nature and cause of the accusation; to be confronted with witnesses against him; to have compulsory process for obtaining witnesses in his favor, and to have the Assistance of Counsel for his defense.(9) It is the "Assistance of Counsel" and the interpretation of Miranda requiring notice to an accused of the right to counsel, and notice of the supplying of free counsel if need be, that is operative in the discussion at hand. The right to counsel had been addressed numerous times by the Supreme Court prior to Miranda. In Johnson v. Zerbst (10), the Court confirmed that this right applied to Federal criminal cases, but it is widely agreed that the landmark case for counsel is Gideon v. Wainwright (11). In this 1963 case, the Court applied the Sixth Amendment through the Due Process clause of the Fourteenth Amendment, thereby requiring States as well as the Federal government to supply appointed counsel in the event a defendant could not afford an attorney. Thus, when Miranda was decided in 1966, the Court was merely re-stating its prior position as to appointed counsel, but also taking the additional step in requiring that a defendant be advised that he had the right to counsel (Sixth Amendment), and to be advised that an attorney would be provided free of charge if one could not be afforded, as per Johnson v. Zerbst and Gideon v. Wainwright.

Figure 1

Supreme Court Justice Opinions and Votes (by Ideology)

Decision: 6 votes for Mapp, 3 vote(s) against

Legal Provision: Amendment 4: Fourth Amendment
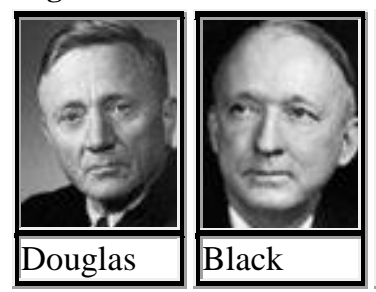

Full Opinion by Justice Tom C. Clark

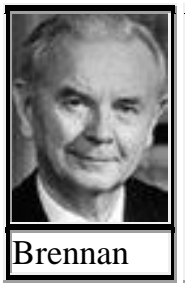

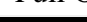

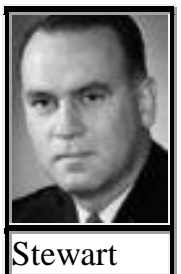

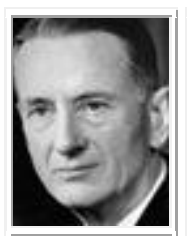

Whittaker

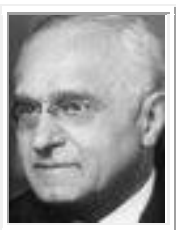

Frankfurter

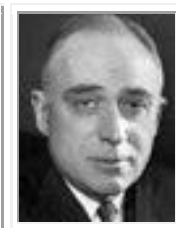

Harlan 


\section{Mapp Discussion}

In 1961, the U.S. Supreme Court decided the case of Mapp v. Ohio (12). Ms. Dollree Mapp's Cleveland, Ohio, home was raided by police without a warrant. They did not find what they were looking for (ironically, a suspected bombing fugitive), but they did find a trunk of pornographic photos and objects. Mapp was convicted for possessing obscene material. Her appeal to the Ohio Supreme Court was denied, and she appealed to the U.S. Supreme court on the grounds that her Fourth Amendment rights were violated. Although the high court had applied the Fourth Amendment to federal prosecutions in the past, and had instituted an "exclusionary rule" for improperly seized evidence in federal cases (13), the 6-3 decision (see Figure 1, above) in Mapp clearly held that the same rule should also apply in state prosecutions by funneling the Fourth Amendment through the Fourteenth Amendment's requirements of imposing due process on the states.

\section{Miranda Discussion}

As stated above, Ernesto Miranda was sentenced to twenty to thirty years in prison. Upon the reversal of his conviction, he was retried, reconvicted and re-sentenced to state prison. He was paroled in 1972. Yet, he continued to have trouble with the law, and was sent back to Arizona State Prison on a parole violation. After his release, he did not get far, in that he was mortally wounded at age 34 with a knife in a bar fight in 1976, short of ten years after the decision bearing his name was handed down. Ironically, the prime suspect in his fatal stabbing elected to stand on his Miranda rights, and refused to cooperate with the police. No one was ever formally charged with the killing.

The Miranda warnings set forth by the Court in its 1966 ruling have weathered the test of time. As recently as 2000, the Supreme Court struck down a federal statute aimed at weakening/limiting the application/enforcement of Miranda.(14) To this date, upon an arrest, the police are supposed to warn an accused: (1) You have the right to remain silent; (2) you have the right to an attorney to represent you in each any every aspect of this proceeding; (3) if you do not have funds to hire an attorney, one will be appointed to you free of charge; and, (4) if you do waive your right to remain silent, and talk to us, anything you say can and will be used against you in a court of law. The sanction imposed against the prosecution is that if the accused is not properly advised of his rights, and if the accused confesses, and if the appropriate, timely (see significance, below) application is made to a court, and if the court finds that the accused's rights have been violated, the confession cannot be used as evidence against him. This does not mean that if the Miranda rights are violated the accused automatically goes free. As happened to Ernesto Miranda in the re-trial stage, if there is sufficient evidence aside from the suppressed confession to convict, a conviction can be obtained. Another irony in the Miranda saga: Although the confession he made to the police was not allowed into evidence in the re-trial, an incriminating statement he made to his common-law wife was allowed into evidence, which, it seems certain, was a factor contributing to his conviction. It seems that Ernesto Miranda did not apply his lesson learned regarding a suspect remaining silent as far as police are concerned to the wisdom of remaining silent, at least at times, when it pertains to responding to inquiries made by a suspecting spouse. Testimony about the statement he made to his common law wife was admitted into evidence over his attorney's objection, the Court at that time holding that spousal privilege did not apply to common-law relationships.

Figure 2

Supreme Court Justice Opinions and Votes (by Ideology)

Decision: 5 votes for Miranda, 4 vote(s) against

Legal Provision: Self-Incrimination
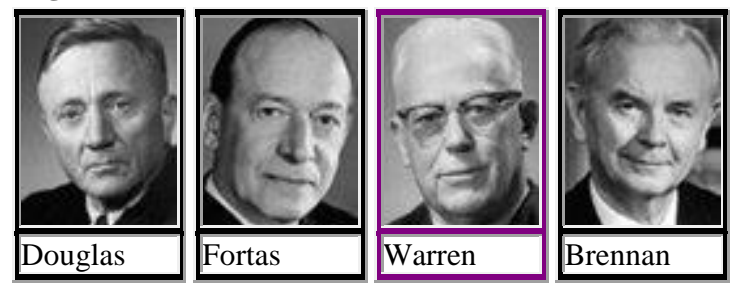

Full Opinion by Chief Justice Earl Warren

Source: The Oyez Project, Miranda v. Arizona, 384 U.S. 436 (1966)
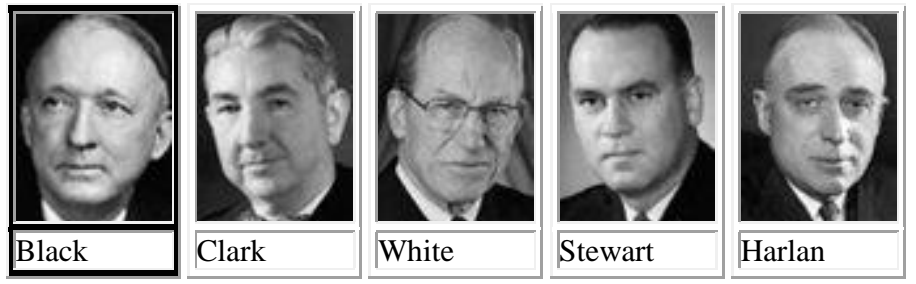


\section{Gideon Discussion}

Gideon v. Wainwright (15) is the landmark case on the right itself to counsel in a criminal proceeding. Clarence Earl Gideon was arrested for allegedly breaking and entering a pool hall in Panama City, Florida in 1961. Facing felony jail time, he requested and was denied an assigned/appointed attorney. Having no funds for an attorney, he represented himself at trial. For his well intentioned efforts, he was found guilty by a jury and sentenced to five years in Florida State Prison. He ultimately appealed to the United States Supreme Court, and was appointed Washington, D.C. attorney, Abe Fortas to represent him. (Note: this is the same Abe Fortas that became a Supreme Court Justice, who was one of the five Justices voting in favor of Miranda in the Court's later 1966 decision, and whose portrait appears above with the Miranda bench.) The decision was 9-0 (see Figure 3, below) in favor of the principle that the states must assign counsel to indigent criminal defendants facing substantial incarceration.

Figure 3

Supreme Court Justice Opinions and Votes (by Ideology)

Decision: 9 votes for Gideon, 0 vote(s) against

Legal Provision: Right to Counsel
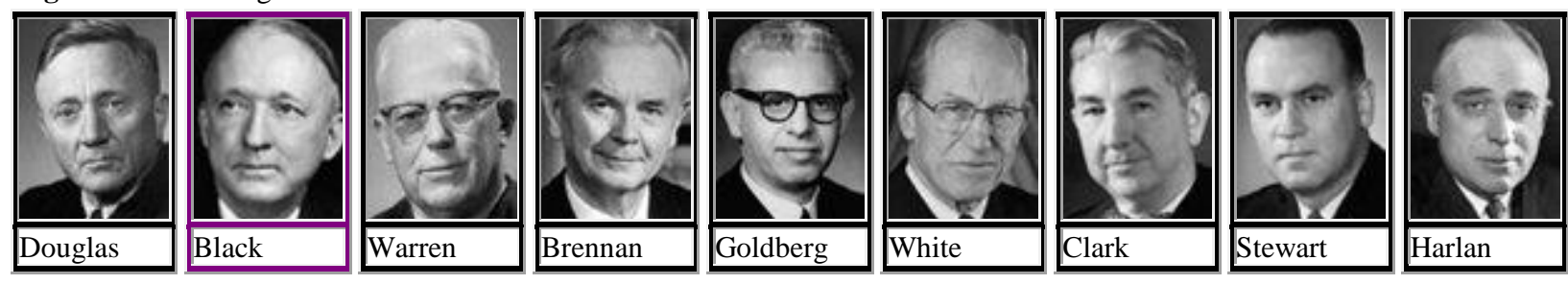

Source: The Oyez Project, Gideon v. Wainwright, 372 U.S. 335 (1963)

\section{In re TERRORIST BOMBINGS OF U.S. EMBASSIES IN EAST AFRICA (16) Discussion}

On August 7, 1998, individuals carried out a conspiracy to bomb U.S. Embassies in Nairobi, Kenya and Dar es Salaam, Tanzania, that resulted in loss of life and property. An investigation ensued. Two suspects, convicted in the District Court in and for the Southern District of New York for their parts in the conspiracy, appealed to the $2^{\text {nd }}$ Circuit Court Of Appeals. The Second Circuit concluded that the claims of defendants Mohamed Rashed Daoud Al-'Owhali and Mohamed Sadeek Odeh as to their Fifth Amendment rights being violated, were properly decided at the District Court level, and, as a result, their convictions were affirmed.

\section{Facts}

Re: Defendant Al-’Owhali.

This defendant was lawfully detained by Kenyan authorities on August 12, 1998, quickly taken to Kenyan police headquarters in Nairobi, and interrogated by an FBI Special Agent, a NYC police detective and two Kenya national police officers. An Advice Of Rights (AOR) form commonly used by U.S. law enforcement personnel operations overseas, written in English, was presented to the defendant. The defendant told the U.S. investigators that he could not read English and had limited understanding of spoken English. The NY detective proceeded to slowly read the form in English to the defendant, stopping at certain junctures for signs of understanding. To the detective, the defendant appeared to understand, replied that in fact he understood when asked, and after having the form read to him, signed his name (using an alias) at the bottom of the form in Arabic. After so signing, the defendant was interrogated for one hour, responding in broken English. Then the investigators decided to continue the interrogation with the use of an interpreter, over a period of between two and four hours. During this time, the AOR form was read in English and then translated to the defendant. In addition, the defendant was interrogated over an additional eight days, the interviewers always referring back to the AOR, and inquiring if the witness 
understood his rights and consented to speak with them. He always consented to speak but denied any knowledge of the bombings.

On August 21, 1998, he indicated he would be willing to talk, if he could be tried in the United States. The next day, he was supplied with a document of understanding (DOU) which, among other things, stated that he had been advised of his rights to remain silent and not to talk to the police without a lawyer, and that the U.S. government would do its best to see he was tried in the U.S. courts. 'Owhali then indicated that he might want an attorney review the DOU, at which time, an Assistant U.S. Attorney recited to him, from memory, through a translator, a rough version of a domestic Miranda warning that did not contain the normal warning that if he could not afford an attorney, one would be provided for him free of charge. The Assistant U.S. Attorney did tell him that there was no American lawyer available to him at that time in Kenya. 'Owhali agreed to proceed despite this situation, but that he wanted clarification as to best efforts to try him in an American court. 'Owhali then said that he wanted to proceed, despite the lack of counsel present, and despite no full guarantee about being tried in the USA. 'Owhali signed the DOU, and was interrogated for three hours on August 23 and 24, and nine hours on August 25. During these times, he admitted his participation in the bombing of the American Embassy in Nairobi. He signed a second DOU on August 25 regarding additional information to be supplied.

\section{Re: Defendant Odeh}

Defendant Odeh was detained in Pakistan on August 7, 1998, on arriving there from Kenya, on the grounds of using a false passport. He was in custody in Pakistan until August 14, when he was sent back to Kenya. He was read, in English, an AOR similar to that read to defendant 'Owhali. He had no trouble conversing in English. He asked about the availability of a lawyer, but did not specifically request one. The Assistant U.S. Attorney suspended the talks to inquire about appointed (not retained) counsel in Kenya, and was advised that Kenya did not have such appointed/assigned counsel available for persons being questioned, and it was their practice in Kenya to continue to question suspects who asked for appointed counsel. The Assistant U.S. Attorney then gave an oral Miranda warning to Odeh. Regarding Counsel, Odeh was advised that he was entitled to have counsel present, and appointed if necessary, but that there was no American attorney available to represent him in Kenya. He signed the AOR on August 15, and was interrogated for approximately seven hours. In the middle of the interrogation, he was again advised that he did not have to proceed without counsel. He nevertheless agreed to continue to talk, on a daily basis. He admitted he was a member of al Qaeda, but denied knowledge of the embassy bombings. On August 27, he was transferred to American custody and given standard Miranda warnings.

\section{The Motions To Suppress Statements, and Decision at District Court Level}

Both defendants moved in U.S. District Court to suppress statements made due to alleged Fifth Amendment/Miranda violations/shortcomings. Defendant Odeh then withdrew his suppression motion, claiming religious grounds regarding swearing to a supporting affidavit. The District Court thereafter granted defendant Al'Owhai's motion to suppress the statements, at which time defendant Odea re-filed his motion to suppress. The U.S. government then filed a motion to reconsider the granting of Al-'Owhai's motion to suppress. The District Court decided to re-open its consideration of the motion(s), indicating more fact finding was appropriate. The District Court then ruled that 'Owhali's motion was granted in part (as to statements made after the AOR) but denied as to statements made after the Miranda warning. As to Odeh's motion, the ruling was that the argument about statements made in Pakistan was untimely (since it had been withdrawn), and the argument about statements made after the oral Miranda warning was dismissed on the merits. With the majority of the statements allowed into evidence, the defendants were convicted.

\section{The Appeal To The Second Circuit and Decision}

The defendants 'Owahi and Odeh appealed to the Second Circuit Court Of Appeals, and on November 24, 2008, the three judge panel of Feinberg, Newman and Cabranes, Circuit Judges, with Judge Cabranes issuing the opinion, basically affirmed the convictions of both defendants as entered by the U.S. District Court.(17) Numerous issues were addressed by Judge Cabranes. There are actually three parts to the decision, but this part of the discussion is limited to the Fifth Amendment Challenges part of the case. As will be seen below, the narrow 
question that gives rise to the sub-title of this paper (Where In The World Is Ernesto Miranda?), is answered with the premise that Miranda protection in fact is found not only in Arizona and throughout the United States proper, but Ernesto Miranda's legacy stretches to even the far corners of the world, to places like Nairobi, Kenya and Karachi, Pakistan.

\section{Re: District Court's Procedural Decisions}

1. Odeh's Withdrawal of his First Motion to Suppress. As was alluded to above, defendant Odeh, after filing a Motion to suppress claiming Fifth Amendment grounds, shortly thereafter got "cold feet" and requested that he be allowed to withdraw his motion, on the grounds that his swearing to an affidavit in support of said motion was contrary to his religious beliefs. The Court allowed him to withdraw the motion, with leave to renew the motion without prejudice in the future. When he became aware, just before trial, that his co-defendant's motion to suppress statements would be granted, at least in part, he then re-filed his prior withdrawn motion to suppress. The trial judge denied this re-filed motion as untimely, as some five or six months had lapsed since the withdrawal. Odeh now claims on appeal, that the trial Judge erred in withdrawal of the initial motion, and that his attorneys violated his Sixth Amendment rights as to effective assistance of counsel in allowing it to be withdrawn and/or not re-filing the motion sooner. Judge Cabranes rejects both arguments in his appellate decision. "Odeh's own actions--in particular, his request, on religious grounds, to withdraw his affidavit in support of the suppression motion and his insistence, again on religious grounds, that his lawyers not re-file the motion-fully explain why his first suppression motion was deemed withdrawn by the District Court and not immediately renewed by his attorneys. Accordingly, he has no basis to complain now that his constitutional rights were violated."(18). And since Odeh instructed his counsel to so proceed, Judge Cabranes flatly stated that deferring to the wishes of counsel does not constitute ineffective assistance of counsel (19). And lastly, the complaint that delay in re-filing was ineffective assistance of counsel, Judge Cabranes concluded that since there was no use of statements from interrogation in Pakistan, there was no prejudice to the defendant (20). In effect: "no harm, no foul."

2. Reopening of defendant Al-'Owhali's Suppression Hearing. As stated above, Judge Sand at the District Court level at first granted, at least in part, this defendant's motion to suppress, based on a perceived failure to comply with Miranda requirements. Yet, upon reconsideration, the motion was denied. Was it error to reconsider? Judge Cabranes concludes it was not error. Citing United States v. Bayless (21) in support of a "second look" based on additional evidence supplied, and the discretion afforded a District Court in so doing, Judge Cabranes affirmed the action as proper. Of great import is Judge Cabranes' observation that the legal question of applying the Fifth Amendment and Miranda to statements made overseas had never been decided by the Second Circuit nor nationally (emphasis added). (22)

Re: The District Court's Denial Of Motions to Suppress Statements, on the Merits.

1. Does the Fifth Amendment and Miranda apply to statements made in foreign custody to U.S. agents? This is the key point of the decision, and the reason for this research paper. As stated above, it is a question of first impression. Judge Cabranes does not mince words: "Like the District Court, we conclude that the admissibility at trial of statements made to U.S. agents by foreign nationals held in foreign custody is governed by the Fifth Amendment...Although we need not decide whether we agree with the District Court as to all the aspects of its ruling on the Fifth Amendment and Miranda, it suffices to hold...that insofar as Miranda might apply to interrogations conducted overseas, that decision is satisfied when a U.S. agent informs a foreign detainee of his rights under the U.S. Constitution when questioned overseas."(23) And further: "We note that U.S. agents acting overseas need not become experts in foreign criminal procedure in order to comply with Miranda; nor need they advocate for the appointment of local counsel on a foreign suspect's behalf. While doing so may provide additional grounds for finding any statements obtained in the course of the interrogations were made voluntarily, it is not required by the Fifth Amendment or Miranda. If the suspect chooses to make a knowing and voluntary waiver of his rights after a warning adapted to the circumstances of questioning overseas and chooses to speak with a U.S. agent, then neither the Fifth Amendment nor Miranda will bar the admission of his statement at trial. (24)

2. Are foreign nationals interrogated overseas but tried in civilian courts of the United States protected by the Fifth Amendment? Judge Cabranes answers this in the affirmative. (25) 
3. Does Miranda govern the admissibility at trial of statements made overseas? Judge Cabranes, citing the Dickerson (26) case, decides that the framework of Miranda generally applies, but that "the application of that framework to overseas interrogation may differ from its domestic application, depending on local circumstances, in keeping with the context-specific nature of the Miranda rule."(27) And further: "Even if we were to conclude, rather than assume, that Miranda applies to overseas interrogations involving U.S. agents, that would not mean that U.S. agents must recite verbatim the familiar Miranda warnings to those detained in foreign lands."(28) The Judge sees a "flexible fashion" accommodation as appropriate. (29)

4. In applying the Fifth Amendment and Miranda to the facts at hand as to the defendants' interrogations, did the U.S. agents comply with the law? The conclusion was "that the AOR substantially complied with whatever Miranda requirements were applicable..."(30) and the oral warning provided by the AUSA also satisfied Miranda. (31)

5. Were the Defendant's waiver of their Miranda rights voluntary? Conclusion again, in the affirmative., upholding the District Court's finding. (32)

6. Were the waivers executed knowingly? Yes, again. (33) Were the statements voluntary? Yes. (34)

\section{The Fourth Amendment Portion Of The Decisions}

As stated above, this paper does not discuss, in detail, the Fourth Amendment aspects of the case. It will take another paper, at another time, to do justice to that discussion. It is significant to note, however, that the conclusion of that portion of the decisions was that the evidence seized in Kenya and surveillance of Kenyan telephone lines was properly admitted at trial because (a) although the "reasonable" portion of the Fourth Amendment applies to searches and seizures of extraterritorial searches of U.S. citizens, the searches were in fact reasonable; and, (b) the "Warrant Clause" of the Amendment does not apply to such searches, and therefore, no warrant was necessary. (35)

\section{CONCLUSION}

Miranda and Mapp have not only weathered the test of time, they have traveled far and wide, across the United States, and abroad. It has been a journey of in excess of forty years. At this point, subject to further action by the U.S. Supreme Court in considering the Second Circuit's convictions of Odea and 'Owhali, they have reached halfway around the world, to Kenya and Pakistan. Based on their history and longevity, it appears that they have many years ahead of them. These horses have not been put out to pasture, and in no way should it be implied that the interpretation and application of these cases are a settled matter. Every day, in every criminal court across the nation (and now, apparently, across the world), the M\&M team, Miranda and Mapp, get to play still, because, although it seems settled that they are the law of the land, prosecutors will continue to seek to limit, by interpretation, the reaches of these cases, and defense counsel will continue to seek to expand, by interpretation, these very same parameters. As has been the case, judges will continue to be required to decide these differences of interpretation and application. And so, depending on the judicial philosophy of the federal judges who hear these cases, at all levels, we will likely continue to revisit the principles set forth in these landmark cases again and again.

\section{AUTHOR INFORMATION}

Patrick J. Reville, B.B.A., J.D., earned his B.B.A. degree in Accounting from Iona College, New Rochelle, New York, in 1965, and the Juris Doctor degree from the Fordham University School Of Law in 1968.

He Joined the Iona College faculty in 1975, and is presently an Associate Professor of Business Law there. Attorney Reville has practiced law and accounting in Westchester County, New York, for forty (40) years, and presently devotes his practice time to Criminal Law, Small Businesses, Real Estate and Estates. 


\section{REFERENCES/FOOTNOTES}

1. $\quad$ Miranda v. Arizona, 384 U.S. 436 (1966).

2. $\quad$ Mapp v. Ohio, 367 U.S. 643 (1961).

3. In re Terrorist Bombings Of U. S. Embassies In East Africa (Fifth Amendment Challenges) 548 F.3d 237 (2d Cir. 2008).

4. $\quad$ Miranda v Arizona, 384 U.S. 436 (1966).

5. The District Court's actions, considerations and reasoning are most fully spelled out in the $2^{\text {nd }}$ Circuit's decision.

6. In re Terrorist Bombings Of U.S. Embassies In East Africa (Fifth Amendment Challenges) 548 F.3d 237 (2d Cir. 2008).

7. U.S. CONST. amend IV.

8. U.S. CONST. amend V.

9. U.S. CONST. amend VI.

10. 304 U.S. $458(1938)$.

11. 372 U.S. $335(1963)$.

12. 367 U.S. $643(1961)$.

13. Weeks v. U.S.,

14. Dickerson v. United States, 530 U.S. 428 (2000).

15. 372 U.S. 335 (1963).

16. $\quad 548$ F.3d 237 (2d Cir. 2008)

17. Ibid.

18. Id. at 254.

19. Id. at 256.

20. Id.

21. U.S v. Bayless, 201 F.3d 115, 131 (2d Cir. 2000).

22. In Re Terrorist Bombings at 258.

23. Id. at 259.

24. Id.

25. Id. at 262 .

26. 530 U.S. 428 (2000).

27. In re Terrorist Bombings at 262.

28. Id. at 264.

29. Id. at 265.

30. Id. at 269.

31. Id. at 271.

32. Id. at 272 .

33. Id. at 273.

34. Id. at 276.

35. In re Terrorist Bombings Of U.S. Embassies in East Africa (Fourth Amendment Challenges) 548 F.3d 276 (2d Cir. 2008). 